\title{
Hi-Value Shoe Store: A Hypothetical Legal Case Study In UCC Article 9 Secured Transactions
}

\author{
Diane Y. Hughes, Rowan University, USA
}

\begin{abstract}
This legal studies case is designed for undergraduate students enrolled in the second level of business law. This second level builds on the areas of legal reasoning, contracts, torts, and business ethics studied in the first level and, generally requires challenging critical thinking. The purpose of this hypothetical case study is to test students' ability to (1) recognize legal issues, (2) analyze and decide legal concepts, and (3) adequately apply the law to the facts.

Students should be familiar with the law of personal property security interests and be able to discuss issues such as competing claims to the collateral, the protections sought by perfecting the security interest, the methods of perfecting and bankruptcy's effect on the both secured and general creditors.
\end{abstract}

Keywords: Secured Transactions; Uniform Commercial Code; Collateral; Perfection; Priority; Foreclosure

\section{INTRODUCTION}

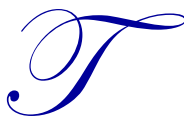

he Uniform Commercial Code (UCC) was enacted to facilitate consistent business laws among the states. It is divided into sections, referred to as Articles, based on the particular area of law. For example, Article 2 governs transactions involving the sale of goods, negotiable instruments law is found in Article 3, and bank deposits and collections is addressed in Article 4.

The subject of this case study is governed by Article 9, Secured Transactions. Specifically, these are cases wherein personal property is used as collateral and a security interest is created.

\section{PREMISE}

Mary is the sole owner of Hi-Value Shoe Store, a small business located in a suburban working class community. She inherited the business from her Aunt Marty three years ago. Up until then, business had been slow because of the declining economy. Lately, however, business has picked up, and revenues have doubled because of an increase in employees at the neighboring manufacturing plant. The plant recently received a valuable contract from the federal government to produce bulletproof vests.

As a result of the increase in business, Mary hired two new full-time employees but was short on the funds necessary for expansion of the business. Mary was able to obtain a loan from Community Bank, but the bank required a security interest and that Mary be personally liable on the note. The language of the security agreement contained the following clause: "The note is secured by the inventory of Hi-Value Shoe Store, currently owned and any later acquired inventory, until said note is fully paid and satisfied." The bank immediately perfected the security interest by filing a financing statement.

Mary decided to purchase inventory from $A B C$ Wholesale Suppliers (ABC) on credit a few weeks after obtaining the loan from the bank. She took possession of the inventory on April 16. ABC required that she sign a promissory note and security agreement, with the inventory being listed as collateral. 
For at least one year, Mary was able to make payments on both obligations from the proceeds of the business. Unfortunately, the manufacturing plant lost its government contract and eliminated $50 \%$ of its workforce over a six-month period. As a result, Mary's business lost customers and began to operate at a loss. It became unable to pay its obligations to both the bank and $\mathrm{ABC}$ and ended up defaulting on both loans.

Both secured parties sought to repossess the inventory from Mary's store, sell the inventory, and then hold Mary personally liable for any deficiency. Mary, aware that she might be held personally responsible for the debt, considered declaring bankruptcy.

\section{QUESTIONS}

1. $\quad$ Discuss and determine which secured party has a priority under UCC Article 9.

2. Assume that the shoe store has sold some of the inventory to Lindsay, a college student. Would the secured parties be able to repossess the shoes from Lindsay?

3. What affect would Mary's filing of Chapter 7 bankruptcy have on the UCC Article 9 foreclosure process?

4. Assume that Mary defaulted on her obligation to ABC but made one late payment to the bank on December 1. Discuss preferential and fraudulent transfers.

\section{An Overview of UCC Article 9 Secured Transactions}

Article 9 of the UCC governs transactions wherein personal property is used as collateral in a security interest. There are several types of personal property that may be used as collateral in an Article 9 security interest. These include "consumer goods, equipment, farm products, inventory, accessions, chattel paper, instruments, accounts, deposit accounts, and general intangibles" as listed in Article 9 of the UCC.

An Article 9 security interest is created when three conditions are met. First, the parties have an agreement or agree to create a security interest. This agreement may be oral or in writing, but, if the secured party takes possession of the collateral, there is no need for a written agreement. Second, the debtor must have ownership rights in the collateral. Third, the secured party must give value to the debtor. For example, a creditor who has made a commitment to loan money or extend credit in a sales contracts must have fulfilled the commitment. effective."

Once all three of these conditions have been met, the security interest is said to have "attached" or "become

Informed secured creditors will usually want to protect themselves from possible competing claims to the collateral that is the subject of their security interest. For example, what happens if the debtor uses the same collateral in a subsequent security interest? Who will have priority rights to the collateral in the event of default?

These concerns can frequently be resolved by means of perfection. Although not required for the creation or attachment of a security interest, perfection is a means by which secured parties attempt to gain priority against competing claims to the collateral. There are three methods of perfecting a security interest. The required method of perfection is dependent upon the classification of the collateral as specified by the UCC. Three commonly used methods of perfection are:

- $\quad$ Filing a Financing Statement: A document is filed by the parties in a governmental office and placed on public record. The statement includes limited information but enough to give notice of the existence of the security interest, such as the names of the parties and a description of the collateral. Where the document is filed may vary from state to state. Some states require the document to be filed in a state office, whereas others may accept the document in the county office where the collateral is located.

- $\quad$ Taking Possession of the Collateral: In some cases, the secured party takes possession of the collateral until the debt is satisfied. At common law, this is known as a pledge. According to Black's Law Dictionary, "to 'pledge' something means to put that thing up as collateral, in return for a loan. The collateral must be returned once full repayment for the loan has been received." 
In business transactions, however, most secured creditors would find this method of perfection to be impractical. For example, assume that Bank A loaned money to Joe's Lawn Service using the company's equipment as collateral. Given that the collateral is necessary to operate the business and generate income, it would be counterproductive for the bank to take possession of equipment until the loan is satisfied. In this scenario, the most likely method of perfection would be filing the financing statement.

- $\quad$ Automatically: Some security interests are automatically perfected. The UCC states that these interests are "perfected upon attachment." A common example is a Purchase Money Security Interest (PMSI) in consumer goods. A PMSI will be created when the secured party is either the financer or the seller of the collateral. A consumer good is defined by the UCC as "goods used or bought primarily for personal, family, or household purposes." In the above example, the bank loaned money to Joe's Lawn Service for the purchase of equipment. A PMSI has been created but it is not automatically perfected because the collateral is equipment rather than consumer goods.

If, however, Joe borrowed the money from the bank in order to purchase a boat for recreational and personal usage, a PMSI is created in a consumer good that would be automatically perfected.

In Mary's case, Community Bank is a secured creditor that owns a floating lien also known as a security interest in after-acquired property. Because inventory is constantly changing, it makes sense that the bank would take an interest in, not only Mary's current inventory, but also any later purchased inventory and its proceeds.

The subsequent security interest held by $\mathrm{ABC}$ is a PMSI in inventory. That interest was attached and perfected after the bank's interest. The general rule of priorities when it comes to competing claims is that of a "first in time," specifically, the first security to perfect or file will have a priority over later perfected security interests. There are some exceptions to the general rule, however, one of which is relevant to both the Community Bank and ABC. According to UCC 9-324(b) if there is a perfected PMSI in inventory that follows a security interest in the same inventory, the PMSI will have priority over the previously perfected security interest if the holder of the PMSI notifies the prior secured party of its interest on or prior to the debtor taking possession of the collateral.

Applying the law to the facts of this case would result in $\mathrm{ABC}$ having a priority over the bank's previously perfected security interest if it notifies the bank of its interest on or before April 16.

\section{Upon Default the Secured Party can take Possession of the Collateral in Order to Satisfy the Debt}

According to UCC 9-609(b), the creditor can use self-help measures to obtain possession of the collateral so long as it does not breach the peace. If the debtor refuses to allow the creditor to enter his/her place of business, the secured party must retreat and resort to obtaining a court order via the legal process.

Once the goods are possessed, the secured party may retain the collateral in satisfaction of the debt or sell the collateral and apply the proceeds to the debt. Assuming the secured party has followed the legal requirements, it may repossess the inventory from Hi-Value Shoe Store.

In the current case question, an additional scenario is present, specifically, the sale of the collateral to Lindsay, a college student. The Code provides that a buyer in the ordinary course of business will take the goods free of any security interest. It defines a buyer in the ordinary course of business as a person who "in good faith and without knowledge that the sale violates the rights of another in the goods, buys in the ordinary course from a person in the business of selling goods of that kind." Assuming that Lindsay is a buyer in the ordinary course of business, neither creditor will be able to repossess the shoes from her.

If, on the other hand, Lindsay purchased the shoes at a sale outside of the ordinary course of business, such as a sale designed to defraud creditors, or, if she purchased a large supply of shoes from her friend Joe who works at the store and advised her of a security interest, she would not qualify for the exemption because she either knew or should have known that the purchase might violate the rights of the secured party. 
Assuming that Lindsay is an ordinary buyer, the secured creditors would not be entitled to repossess her shoes even if she had notice of their security interest.

\section{If Mary were to File for Bankruptcy, The Automatic Stay is Invoked}

Bankruptcy is designed to give debtors a fresh start. In a Chapter 7 bankruptcy, the assets of the debtor, with some exceptions, become part of the bankruptcy estate. A bankruptcy trustee is assigned who is responsible for gathering and selling the assets and distributing the proceeds from the sale to the creditors.

The filing of a bankruptcy petition will result in an immediate cessation of most collection actions by creditors. This is what the Bankruptcy Code refers to as an Automatic Stay. Generally, creditors cannot contact the debtor or attempt to collect the debt without risking penalties imposed by the Code.

Within the hierarchy of distribution, secured creditors will have priority over general creditors. If Mary files for bankruptcy, most likely all repossession proceedings will be stopped.

\section{The Late Payment to the Bank may be Classified as a Preferential Transfer}

Preferential transfers result when the insolvent debtor makes a payment to a pre-existing creditor within 90 days prior to the filing of the bankruptcy petition and that payment results in the debtor receiving more than would have been received in bankruptcy. In this case, Mary made a payment on December 1. If she filed a bankruptcy petition within the next 90 days, that payment may be deemed preferential. Because the law presumes that debtors are insolvent for the 90 days prior to filing, the payment to the bank can be set aside and considered part of the bankruptcy estate by the trustee.

Following are some exceptions to preferential transfers: (1) payment of current obligations, (2) domestic support payments, and (3) certain payments by consumers.

Fraudulent transfers are different from preferential transfers. Say, for example, Mary transferred some of her inventory or other assets to Bob, her friend, for so-called "safe keeping."

If such a transfer was made within two years prior to filing the bankruptcy petition and was intended to defraud, delay or hinder a creditor, the trustee may be able to obtain the property and bring it back into the estate.

\section{TEACHING END NOTES}

Additional questions for class discussion. Divide the students into two groups and assign them opposing viewpoints on the following questions:

1. What are some of the ethical considerations if Mary decides to file for bankruptcy protection?

2. Assume you are one of the two new employees hired during the increase in business. Would you remain loyal to the business or seek employment elsewhere? Defend your position.

3. Assume the role of a business consultant. What advice would you give Mary?

\section{AUTHOR INFORMATION}

Diane Y. Hughes is an Associate Professor in the Accounting/Finance Department of the Rohrer College of Business, Rowan University. She holds an MBA and Juris Doctorate degrees and is a member of the New Jersey Bar. She teaches Accounting and Business Law courses at the undergraduate level. E-mail: Hughes@rowan.edu

\section{REFERENCES}

1. Black's law dictionary free online dictionary ( $2^{\text {nd }}$ ed.). Retrieved from http://thelawdictionary.org/pledging/ 2. Uniform Commercial Code Article 9 